\title{
Workaholism Components in Relation to Life and Work Values
}

\author{
Diana Malinowska ${ }^{1} \cdot$ Aleksandra Tokarz $^{1}$
}

Published online: 10 May 2019

(C) The Author(s) 2019

\begin{abstract}
Two studies were conducted to examine the association of two workaholism components (drive to work and work enjoyment) with life and work values. Study 1 examined whether life values that are lower on the ideal value hierarchy predict the drive to work; and whether life values that are higher on the hierarchy predict work enjoyment. Study 2 tested the hypotheses that extrinsic work values predict the drive to work, whereas intrinsic work values predict work enjoyment. The results of study 1 showed that moral values, which represent higher order life values, were negatively correlated with the drive to work and positively correlated with work enjoyment. Work enjoyment was also negatively associated with vital values, which have a low position on the ideal life values hierarchy. Hypotheses about the relationships between the two workaholism components and life and work values were not fully confirmed.
\end{abstract}

Keywords Workaholism · Drive to work · Work enjoyment · Work values · Life values

\section{Workaholism and Its Components}

The debate about the positive and negative aspects of workaholism has led scholars to distinguish between different types of workaholism (e.g. Naughton 1987; Scott et al. 1997; Spence and Robbins 1992) and this continues to be a subject of contemporary research (Burke 2000c; Johnstone and Johnston 2005; Van Beek et al. 2011). One of the important questions that follows from the debate is whether workaholism should be reduced in organisations (Burke 2000a; Burke 2008). Although most researchers equate workaholism with other addictions that are harmful to health, social relations, and performance (Killinger 1991; Oates 1971; Robinson 1996), more attention needs to be focused on its complex nature to answer this question. Simply stating that someone is addicted to work and needs help is not sufficient. Workaholism, like other addictions (Jellinek 1960; Griffiths et al. 2018; Malinowska

Diana Malinowska

d.malinowska@uj.edu.pl

1 Institute of Psychology, Jagiellonian University, Ingardena 6, 30-060 Kraków, Poland 
2018), may develop over time, from excessive work and a work-life imbalance, accompanied by high work satisfaction and an average level of internal pressure to work, to lack of control over working, and strong negative feelings when deprived of work.

Workaholism is clearly a multi-faceted phenomenon, as indicated by different definitions that focus on its various manifestations. Although there is still no consensus about its definition among researchers, contemporary conceptualizations characterise workaholism as a group of co-occurring symptoms (Andreassen et al. 2014; Aziz and Zickar 2006).

One of the earliest empirically validated definitions was proposed by Spence and Robbins (1992) who considered workaholism to be a syndrome. According to Spence and Robbins, a workaholic is a person who possesses three main characteristics: (1) a sense of compulsion to work arising from internal pressure, (2) high commitment to work, and (3) low work enjoyment. In addition, they distinguished an enthusiastic workaholic type, which is characterised by high levels of drive to work and work involvement, and a high level of work enjoyment. The three identified dimensions of workaholism are labelled the 'workaholic triad' and an instrument created to measure them (Workaholism Battery, WorkBAT) is used in many studies of this phenomenon (Snir and Harpaz 2012).

Our study included two of the three original workaholism components: drive to work and work enjoyment. The rationale for limiting the number of components was based on research conducted in other cultures (e.g. Turkish, Polish, New Zealand, Norway) that underscore the advantage of a two-factor over a three-factor structure of the WorkBAT (e.g. Andreassen et al. 2007; Malinowska et al. 2010; McMillan et al. 2002).

The main advantage of using these two components in research on workaholism is that they represent both the negative (i.e. drive to work) and positive (i.e. work enjoyment) aspects of this construct. The dual nature of workaholism has been empirically demonstrated in research that analysed workaholism components or types of workaholism in relation to health consequences (Burke 2000c; Burke et al. 2004; Johnstone and Johnston 2005) and their motivational antecedents (Van den Broeck et al. 2011). In addition, the decision to view workaholism as being composed of negative and positive aspects is in keeping with the more contemporary conceptualization of workaholism proposed by $\mathrm{Ng}$ et al. (2007). These authors identified cognitive, behavioural, and affective dimensions of workaholism and proposed components that are relevant to the three dimensions.

The drive to work is a cognitive component of workaholism; it appears in many conceptualizations of workaholism, which regard it as the stable tendency to work excessively and compulsively (e.g. Andreassen 2014; Oates 1971; Robinson 1996; Schaufeli et al. 2008). A person who has a strong drive to work feels an inner urge, and/or an obsession with work. He or she feels an internal obligation to work, even if external sources of pressure, such as the requirements of the workplace or the supervisor, are absent. Work enjoyment is the second aspect analysed in the study. It is an affective component of workaholism. A person who has a high level of work enjoyment takes pleasure from their work and likes it because it is intrinsically interesting (Johnstone and Johnston 2005; McMillan et al. 2002; Spence and Robbins 1992). In addition, some conceptualizations (e.g. Wojdylo et al. 2013) consider positive emotions experienced at work to have a compensatory function for workaholics.

Although researchers have paid considerable attention to the outcomes of workaholism related to psychological and work well-being (e.g. Clark et al. 2014), a compelling case can be made for devoting more research attention to the antecedents of workaholism. A proposal to include values in the analysis of the antecedents of workaholism was suggested by Liang and Chu (2009) in their theoretical model. To date, evidence on the predictors of drive to work and 
work enjoyment is limited to types of motivation (Malinowska et al. 2018; Van den Broeck et al. 2011), whereas the role of values remains untested. The present study was designed to address this gap in the literature. In particular, we examined life and work values as potential predictors of drive to work and work enjoyment. This investigation should contribute to knowledge about the personality and, particularly, the motivational antecedents of workaholism, and add to a further differentiation between its components.

\section{Life and Work Values}

Values have an important effect on an individual's attitude and behaviour. In psychology, values are a core personality construct that is strongly connected to the choice of action and behaviour and underlies the specification of goals (Bargh et al. 2010; Guttman 1982; Rokeach 1973, 1979; McClelland 1986; Sagie 1993). As noted by Latham (2007, p. 150), who differentiated between values and goals: 'Goals are the mechanism by which values lead to action'. Schwartz (2005) explained this mechanism and defined values as abstract motivational beliefs concerning trans-situational goals, varying in importance and containing information about what is important for the individual. This definition is congruent with an early conceptualization of values by Allport (1961), who stated that values are beliefs that cause individuals to act on their preferences.

A similar approach to values was presented by Brzozowski (2007) who postulated, referring to a phenomenological philosophy (Scheler 1975; Tischner 1984), that life values form an ideal hierarchy. The ideal hierarchy of values divides values into four subgroups, starting from the least important these are as follows: hedonistic values, vital values, spiritual values consisting of moral, truth and aesthetic values, and holy values (both secular and religious). The order of values in the ideal value hierarchy has its roots or foundation in European cultural heritage (Brzozowski 2005) and can be treated as a pattern or reference point to analyse an individual's hierarchy of values.

Although many authors recognise the universality of values, not everyone is willing to claim that there is the ideal hierarchy of life values (e.g. Schwartz 1992). However, the assumptions that there is an ideal hierarchy of values, as proposed by Brzozowski (1995, 2007), are supported by empirical evidence. The theory argues that the emotional, cognitive, and social maturation of individuals should lead to exploring and learning more fully about the ideal hierarchy. Studies have shown that the value hierarchies of criminals and alcoholics are less similar to the pattern of the ideal hierarchy compared to the value hierarchy of seminarians, clergy, and scouts (Brzozowski 1992, 2007). The relationships among the ideal value hierarchy, personality determinants of mental health, and social adjustment also have been empirically verified. Brzozowski (2007), who used subscales of the California Personality Inventory (CPI), obtained significant positive correlations between the similarity of an individual's hierarchy to the pattern of the ideal hierarchy and health indicators, such as personal adjustment, mental health, social adaptation, and adherence to standards.

Thoresen and his colleagues (Thoresen et al. 2003) demonstrated that individuals who value work, family, and religion on the same level as personal values are more enthusiastic and active at work. This relationship was confirmed by another group of researchers, who showed that the appreciation of values such as work, family, and religion is an important predictor of positive mood at work (Hyde and Weathington 2006). 
Although values are inherent in most work-motivation theories (Locke and Henne 1986), few vocational theories incorporate work values as a construct of central importance. Three of the best-known theories in the vocational literature that do address work values are Super's Life-Span, Life-Space theory (Super 1953), the Theory of Work Adjustment (Dawis and Lofquist 1984), and Duane Brown's ValuesBased, Holistic theory (Brown 1996). In our study, we selected Super's proposition (Super 1953), in which work values are defined as professional goals that an individual considers to be important and desirable and tries to achieve in his or her career. Super (1970) notes that work values can be used to assess one's motivation to work. These work-related values are as follows: altruism, aesthetics, achievement, changeability, co-workers, creativity, income, independence, intellectual stimulation, lifestyle, management, prestige, promotion, security, supervisory relations, and workplace. Super's original classification of work values included seven categories: (1) external work values, (2) autonomy and intellectual stimulation, (3) relationships and workplace, (4) altruism, (5) aesthetics, (6) achievements, and (7) others, not classified. The meaning of each work value and its category are presented in Table 1.

Super's classification of work values is complementary to other researchers' suggestion that work values can be classified as extrinsic or intrinsic (George and Jones 1997; Nord et al. 1990). One definition describes intrinsic work values as desired endstates that depend on the content of the work, and extrinsic values as being independent of the content of the work (George and Jones 1997). Based on Deci and Ryan's

Table 1 The meaning of the 16 work values in Super's conceptualization

\begin{tabular}{|c|c|c|}
\hline Work value & Meaning of work value & Category \\
\hline Altruism & Enables individuals to contribute to the welfare of others & Altruism \\
\hline Aesthetics & Permits or inspires individuals to contribute to the beauty of the world & Aesthetics \\
\hline Achievement & Gives individuals a feeling of accomplishment in doing a job well & Achievements \\
\hline Changeability & Permits individuals the opportunity to perform different types of jobs & Other \\
\hline Co-workers & $\begin{array}{l}\text { Associated with having enjoyable interpersonal working relationships with } \\
\text { colleagues }\end{array}$ & $\begin{array}{l}\text { Social relations } \\
\text { and conditions }\end{array}$ \\
\hline Creativity & $\begin{array}{l}\text { Permits or inspires individuals to invent new things, design new products } \\
\text { or develop new ideas }\end{array}$ & $\begin{array}{l}\text { Autonomy and } \\
\text { stimulation }\end{array}$ \\
\hline Income & Pays well or otherwise enables individuals to obtain the things they want & External \\
\hline Independence & $\begin{array}{l}\text { Allows or encourages individuals to control the manner in which they } \\
\text { perform their work }\end{array}$ & $\begin{array}{l}\text { Autonomy and } \\
\text { stimulation }\end{array}$ \\
\hline $\begin{array}{l}\text { Intellectual } \\
\text { stimulation }\end{array}$ & $\begin{array}{l}\text { Provides opportunity for independent thinking and for learning how and } \\
\text { why things work }\end{array}$ & $\begin{array}{l}\text { Autonomy and } \\
\text { stimulation }\end{array}$ \\
\hline Lifestyle & $\begin{array}{l}\text { Associated with the kind of work that allows individuals to live the kind of } \\
\text { life they choose and to be the type of person they wish to be }\end{array}$ & Other \\
\hline Management & Permits individuals to plan and assign work to others & External \\
\hline Prestige & Gives individuals standing in the eyes of others and evokes respect & External \\
\hline Promotion & Having an opportunity to improve one's own professional position & External \\
\hline Security & $\begin{array}{l}\text { Associated with work that provides individuals with confidence in their } \\
\text { continued employment }\end{array}$ & External \\
\hline $\begin{array}{l}\text { Supervisory } \\
\text { relations }\end{array}$ & $\begin{array}{l}\text { Associated with maintaining a collegial relationship with an individual's } \\
\text { supervisors }\end{array}$ & $\begin{array}{l}\text { Social relations } \\
\text { and conditions }\end{array}$ \\
\hline Workplace & Having work that is performed in pleasant conditions & $\begin{array}{l}\text { Social relations } \\
\text { and conditions }\end{array}$ \\
\hline
\end{tabular}

Author's own elaboration, based on Super (1985) 
theory of the source of motivation (the Self-Determination Theory, SDT), it is also possible to distinguish between intrinsic and extrinsic goals. Intrinsic goals are defined as those pursuits that are generally congruent with the psychological needs for relatedness, autonomy, and competence, as proposed by SDT (Deci and Ryan 1985, 2000; Kasser 2002; Sheldon and Elliot 1998, 1999), and are inherently satisfying to pursue, in and of themselves. In contrast, extrinsic goals are primarily concerned with obtaining rewards or social praise; because they are typically means to some other ends or they compensate for problems in need satisfaction, they are less likely to be inherently satisfying (Deci and Ryan 2000).

It can be assumed that Super's original category of autonomy and stimulation, which includes creativity, independence, and intellectual stimulation, is congruent with intrinsic values. External values in his classification, including income, management, prestige, promotion, and security, have the same meaning as they do in the aforementioned propositions that distinguish extrinsic values. Having an intrinsic work value orientation and a high regard for intrinsic values is considered to be particularly beneficial. Deci and Ryan (2000) found that individuals who are motivated by extrinsic goals and external sources of motivation report lower levels of satisfaction and psychological health compared to those who pursue intrinsic goals. Other research also suggests that employees who value intrinsic aspects of their job are more creative and self-directed and prefer to learn new skills, and that this leads to job satisfaction and enthusiasm (Knoop 1994). Therefore, the intrinsic and extrinsic work values classification may be used to assess psychological well-being.

\section{Workaholism Components, Life, and Work Values}

We should consider the nature of the different components of workaholism when regarding their relationship with values. A study by Adreassen and colleagues (Andreassen et al. 2007) found that different components of workaholism have different relationships with health symptoms. The drive to work was correlated positively with all job stress scales, whereas work enjoyment was correlated negatively with all job stress scales except the promotion scale. The drive to work was also positively correlated with emotional exhaustion and absorption. In contrast, burnout scales were negatively related to work enjoyment.

Another study found that work enjoyment was positively related to general self-efficacy (Burke et al. 2006). This result signifies that people who enjoy their work expect their work activities to be successful and have a sense of control over them. Feeling driven to work was positively related to neuroticism, which represents a high level of anxiety and inhibits free choice and self-control.

A study by Graves and colleagues (Graves et al. 2012) found that individuals who reported higher levels of drive to work had lower self-esteem in contrast to those who reported higher levels of work enjoyment. Moreover, individuals with higher levels of work enjoyment had higher performance and career satisfaction and less psychological strain. There were no significant correlations between the aforementioned variables and drive to work.

There is a lack of research on the relationship between workaholism and life values. Machlowitz (1980) suggested, based on 100 interviews with workaholics, that workaholics appreciated work and being productive at the expense of other activities. A study by Paluchowski and Hornowska (2003) found that work was the most significant value for workaholics. They treated work as a domain for achieving other important things they valued, 
such as gaining admiration and respect, influencing other people, achieving higher career levels, and improving their own skills. Their two least important values were relationships and social interactions.

It can be assumed that the life values of workaholics, who appreciate work more than they do other values, are not arranged in the ideal value hierarchy, in which the highest values are holy and spiritual values (consisting of moral, truth, and aesthetic values) and the lowest values are vital and hedonistic values.

However, taking into account the research findings about the different nature of the two components of workaholism and the assumption that the ideal value hierarchy indicates more mature personality, it is reasonable to expect that:

Hypothesis 1: The drive to work can be predicted by lower order values of the ideal value hierarchy (hedonistic and vital values). The higher the level of hedonistic and vital values, the higher the level of the drive to work.

Hypothesis 2: Work enjoyment can be predicted by higher order values of the ideal value hierarchy (moral, truth and aesthetic values, secular and religious holy values). The higher the level of moral, truth, aesthetic values, secular and religious holy values, the higher the level of work enjoyment.

As noted earlier, the drive to work and work enjoyment correlate differently with health indicators, including neuroticism, self-efficacy, and self-esteem. In addition, there are differences between these workaholism components and their link to motivation. Researchers (e.g. Burke and Fiksenbaum 2008) see them as representing different underlying motivations or orientations to work.

A study by Van den Broeck and colleagues (Van den Broeck et al. 2011) provides evidence that people work compulsively because they are concerned about extrinsic rewards or punishment. The study found that compulsive working was related positively to controlled motivation.

These results were confirmed in another study that used the SDT's types of motivation regulation (Van Beek et al. 2011). The researchers confirmed that workaholic employees were significantly more driven by external regulation than were engaged workaholics. These types of workaholics differ in their level of work engagement, which is defined as a positive fulfilling work-related state of mind (Schaufeli et al. 2002). Moreover, the study revealed that both engaged employees and engaged workaholics are driven by autonomous motivation.

Thus, when drive to work arises from external sources of motivation and work enjoyment comes from internal sources of motivation and the free pursuit of activities, we propose:

Hypothesis 3: The drive to work is predicted by extrinsic work values (income, management, prestige, promotion, and security). The higher the level of income, management, prestige, promotion, and security, the higher the level of the drive to work.

Hypothesis 4: Work enjoyment is predicted by intrinsic work values (creativity, independence, and intellectual stimulation). The higher the level of creativity, independence, and intellectual stimulation, the higher the level of work enjoyment.

The hypotheses 1 and 2 were tested in study 1, whereas the hypotheses 3 and 4 were tested in study 2 . 


\section{Study 1}

\section{Method}

\section{Participants and Procedure}

The participants consisted of 137 Polish managers who were students or graduates of Master of Business Administration (MBA) programmes in Poland. The purposive sampling method was used. The selection criteria for participation in the study were as follows: participants had to work at least in a middle-level management position, have at least 2 years of work experience at a managerial level, and be working fulltime in organisations with more than 250 employees. These criteria were used to select cases of potential workaholism which can be mainly found in white-collar jobs which are characterised by high complexity, work pressure, risk-taking, uncertainty, and changeability of work methods (Kanai and Wakabayashi 2001; Johnstone and Johnston 2005). The participants were invited to participate in the study either personally by a researcher during a class, or through an e-mail sent by a representative of the MBA schools. The response rate for personal contact was $25 \%$. The response rate is difficult to assess for the e-mails sent by the MBA schools because it is impossible to know how many e-mails were received (some e-mail addresses of MBA graduates might be outdated). The paper form of the questionnaire was completed by 111 people, and the online form was completed by 75 people. The influence of the form on the structure of relationships between variables was controlled and was insignificant.

The results from 137 people were analysed from 95 people completing the paper form and 42 people completing the online form, owing to incomplete provision of data. Over a quarter $(27.7 \%)$ of the participants were women, $70.8 \%$ were men, and $1.5 \%$ did not provide data on their gender. Their average age was 36 years $(S D=6.2)$, with an age range from 25 to 55 years. All the participants were employed full-time in managerial positions within different organisations located in different regions of Poland. Their average job tenure was 12.62 years $(S D=6.01)$. The proportion of participants who were married was $68.6 \%$; $26.3 \%$ were single and had never been married; and $2.9 \%$ were divorced. On average, they worked $49.44 \mathrm{~h}$ per week $(S D=$ 9.28). The average number of working hours in Poland is 46 (CBOS 2012).

\section{Measures}

\section{Components of Workaholism}

Two subscales of the Workaholism Battery, developed by Spence and Robbins, which was adapted to Polish conditions (Malinowska et al. 2010), were used: (1) Feeling Driven to Work/Drive to Work - an internal feeling of pressure and a need to work that is unrelated to external requirements, e.g. 'I feel guilty when I take a day off' $(\alpha=.79)$; (2) Work Enjoyment-deriving pleasure from performing work, e.g. 'Most of the time my job is very enjoyable' $(\alpha=.62)$. Each participant rated the degree to which each statement conformed with his/her own beliefs on a 5 -point scale $(1=$ 'I definitely agree'; 5 = 'I definitely disagree'). 


\section{Life Values}

The Scheler's Values Scale (version D), which was developed by Brzozowski (1995), consists of 50 values that comprise six scales: hedonistic values (e.g. 'pleasure', $\alpha=.84$ ), vital force values (e.g. 'physical strength', $\alpha=.89$ ), aesthetic values (e.g. 'elegance', $\alpha=.85$ ), truth values (e.g. 'knowledge', $\alpha=.90$ ), moral values (e.g. 'kindness', $\alpha=.90$ ), and sacred values (e.g. 'faith', $\alpha=.87$ ). The values are ordered alphabetically. The task of the participant is to assess each value on a 100-point scale $(0=$ 'not important', to $100=$ 'most important') independent of the other values. This tool measures the subjective importance of values and the level of agreement between an individual's subjective hierarchy of values and the ideal hierarchy of values.

\section{Results}

Means, standard deviations, and correlations between variables are presented in Table 2. Multiple regression analyses on SPSS were conducted in which each of the life values was regressed on drive to work and work enjoyment to test the hypotheses about life values as potential predictors of the two components of workaholism. As shown in Table 3, life values explained very little of the variance in either component of workaholism: drive to work $\left(R^{2}=.06, p=.50\right)$ and work enjoyment $\left(R^{2}=.08, p=.19\right)$.

The drive to work was negatively related to moral values $(\beta=-.30, p=.04)$. Work enjoyment was positively related to moral values $(\beta=.31, p=.04)$ and negatively related to vital values $(\beta=-.27, p=.03)$.

Table 2 Means, standard deviations, and zero-order correlations between study variables

\begin{tabular}{|c|c|c|c|c|c|c|c|c|c|c|c|c|}
\hline Variable & $\begin{array}{l}\text { Number of } \\
\text { items }\end{array}$ & M & SD & 1 & 2 & 3 & 4 & 5 & 6 & 7 & 8 & 9 \\
\hline \multicolumn{13}{|c|}{ Workaholism components } \\
\hline 1. Drive to work & 6 & 23.1 & 5.95 & - & -.16 & -.11 & -.00 & -.01 & -.11 & $-.24 * *$ & -.13 & -.11 \\
\hline $\begin{array}{l}\text { 2. Work } \\
\text { enjoyment }\end{array}$ & 8 & 9.9 & 1.99 & & - & .02 & -.09 & .07 & .08 & $.18^{*}$ & .00 & .03 \\
\hline \multicolumn{13}{|c|}{ Lower order life values } \\
\hline $\begin{array}{l}\text { 3. Hedonistic } \\
\text { values }\end{array}$ & 8 & 68.1 & 14.07 & & & - & $.48 * *$ & $.59 * *$ & $.50^{* *}$ & $.30 * *$ & .01 & .17 \\
\hline 4. Vital values & 6 & 44.8 & 20.00 & & & & - & $.67 * *$ & $.37 * *$ & $.26^{* *}$ & -.05 & -.00 \\
\hline \multicolumn{13}{|c|}{ Higher order life values } \\
\hline $\begin{array}{l}\text { 5. Aesthetic } \\
\text { values }\end{array}$ & 7 & 50.0 & 17.86 & & & & & - & $.46^{* *}$ & $.44 * *$ & .15 & $.23 *$ \\
\hline 6. Truth values & 8 & 77.8 & 14.18 & & & & & & - & $.50 * *$ & .15 & $.29 * *$ \\
\hline 7. Moral values & 11 & 71.6 & 15.65 & & & & & & & - & $.51 * *$ & $.52 * *$ \\
\hline $\begin{array}{l}\text { 8. Holy secular } \\
\text { values }\end{array}$ & 6 & 46.8 & 25.30 & & & & & & & & - & $.79 * *$ \\
\hline $\begin{array}{l}\text { 9. Holy religious } \\
\text { values }\end{array}$ & 4 & 51.4 & 32.43 & & & & & & & & & - \\
\hline
\end{tabular}

$* p<.05 ; * * p<.01$ 
Table 3 Multiple regression analyses predicting drive to work and work enjoyment, with life values as independent variables

\begin{tabular}{lcc}
\hline Variable & Drive to work & Work enjoyment \\
\hline & Beta & \\
Lower order life values & & \\
$\quad$ Hedonistic values & -.14 & -.04 \\
$\quad$ Vital values & .01 & $-.27^{*}$ \\
Higher order life values & & .16 \\
$\quad$ Aesthetic values & .19 & -.01 \\
Truth values & .10 & $.31^{*}$ \\
Moral values & $-.30^{*}$ & -.15 \\
Holy secular values & .00 & -.12 \\
Holy religious values & -.01 & .09 \\
$R^{2}$ & .06 & 1.45 \\
$F$ & .91 & \\
\hline
\end{tabular}

${ }^{*} p<.10 ; * * p<.01 ; * * * p<.001$

\section{Study 2}

\section{Method}

\section{Participants and Procedure}

Participants were recruited from a Polish production company. The convenience sampling method was used. Research questionnaires were given to 150 full-time employees and 81 of them were returned, yielding a 54\% response rate. Complete data were available for 72 employees. The sample included 29 women and 43 men; their mean age was 36 years $(S D=8.77)$. The sample represented middle-level management $(14 \%)$, specialists $(44 \%)$, administrative jobs (14\%), and production jobs (28\%); $53 \%$ of the participants had a university degree and $47 \%$ had a graduate degree.

\section{Measures}

\section{Workaholism}

Two subscales of the Workaholism Battery (Spence and Robbins 1992) that were used in study 1 were also used in study 2 to assess the components of workaholism.

\section{Work Values}

The Work Values Orientations scale developed by Seifert and Bergmann (1983) was adapted for use in the Polish context by Zalewska (2000). It assesses the following 16 values: achievement $(\alpha=.55)$, aesthetics $(\alpha=.86)$, altruism $(\alpha=.92)$, changeability $(\alpha=.79)$, coworkers $(\alpha=.55)$, creativity $(\alpha=.87)$, income $(\alpha=.81)$, independence $(\alpha=.72)$, intellectual stimulation $(\alpha=.88)$, lifestyle $(\alpha=.54)$, management $(\alpha=.89)$, prestige $(\alpha=.84)$, promotion $(\alpha=.90)$, security $(\alpha=.73)$, supervisory relations $(\alpha=.89)$, workplace $(\alpha=.90)$. The scale consists of 48 items, with each work value measured by 3 items. The items were rated on a 5 point scale ranging from 1 (completely unimportant to me) to 5 (very important to me). 


\section{Results}

Means, standard deviations, and correlations between variables are presented in Table 4. It should be noted that the relationship between the drive to work and work enjoyment was positive and significant $(r=.29, p<.01)$, whereas this relationship was negative and insignificant in study 1 , which might be explained by differences in the samples and procedures of conducting these two studies. The drive to work is a cognitive component and work enjoyment is an emotional component of workaholism. They should be treated as independent to some extent, based on the weak and positive correlation between them in the present study 2 and in previous research of other authors (e.g. Burke 2000b). Taking these into account, we decided to analyse them separately rather than using a simultaneous equations approach with one higher order construct. Multiple regression analyses on SPSS were conducted to test the hypotheses about work values as predictors of the two components of workaholism. The results of the analyses are presented in Table 5. Work values explained a significant amount of the variance in drive to work $\left(R^{2}=.43, p=.004\right)$ and work enjoyment $\left(R^{2}=.62, p<.001\right)$.

The higher their level of drive to work, the higher participants rated the importance of intellectual stimulation $(\beta=.34 ; p=.001)$, income $(\beta=.23 ; p=.02)$, and supervisory relations $(\beta=.20 ; p=.04)$. The higher their level of drive to work, the lower participants rated the importance of challenge $(\beta=-.26 ; p=.01)$, security $(\beta=-.23 ; p=.02)$, and achievement $(\beta=-.19 ; p=.04)$.

The higher their level of work enjoyment, the higher participants rated the importance of independence $(\beta=.43 ; p<.001)$ and the workplace $(\beta=.35 ; p<.001)$. The higher their level of work enjoyment, the lower they rated the importance of aesthetics $(\beta=-.37 ; p<.001)$, management $(\beta=-.37 ; p<.001)$, security $(\beta=-.32 ; p<.001)$, prestige $(\beta=-.30 ; p<.001)$, and supervisory relations $(\beta=-.22 ; p<.01)$.

\section{Discussion}

There has been a great deal of interest in the correlates of workaholism among scholars and practitioners in recent years. Although much is known about its potential consequences, there is little empirical evidence on the source of workaholism. The purpose of this study was to analyse the role of life and work values in predicting the drive to work and work enjoyment. In psychology, values are significant mechanisms influencing behaviour, motivation, cognition, and affect. They may also be used as indicators of a well-adjusted and mature personality.

We expected that the drive to work and work enjoyment would be predicted, respectively, by lower order life values (hedonistic and vital values) and higher order life values (moral, truth and aesthetic values, secular and religious holy values) in the ideal value hierarchy. It was found that these two components were diversely related to moral values. The association between drive to work and moral values was negative, whereas it was positive for work enjoyment. Specifically, those who had a compulsive drive to work hard did not appreciate honesty, kindness, or generosity in relationships with others. This interesting finding may explain why workaholics have poor professional and family relationships (e.g. Killinger 1991; Robinson 1996). If they do not appreciate the qualities related to having good relationships with others, they are likely to have difficulties in this area. 


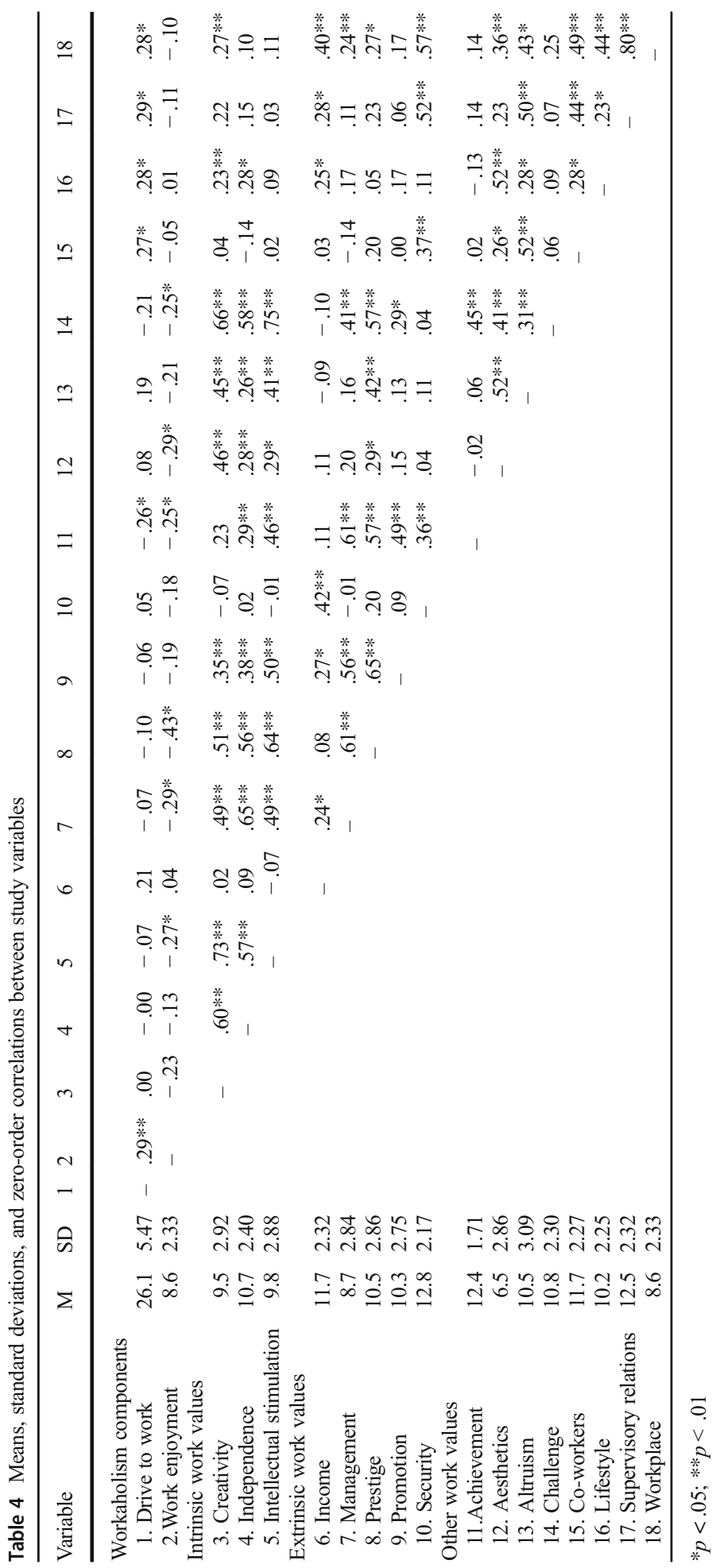


Table 5 Multiple regression analyses predicting drive to work and work enjoyment with work values as independent variables

\begin{tabular}{lcc}
\hline Variable & Drive to work & Work enjoyment \\
\hline & Beta & \\
Intrinsic work values & & \\
Creativity & .11 & .03 \\
Independence & .19 & $.43^{* * *}$ \\
Intellectual stimulation & $.34^{* * *}$ & -.01 \\
Extrinsic work values & $.23^{*}$ & .12 \\
Income & -.19 & $-.37^{* * *}$ \\
Management & .01 & $-.29^{* * *}$ \\
Prestige & -.07 & .08 \\
Promotion & $-.23^{*}$ & $-.32^{* * *}$ \\
Security & & .06 \\
Other work values & $-.19^{*}$ & $-.32^{* * *}$ \\
Achievement & -.10 & .03 \\
Aesthetics & .00 & -.14 \\
Altruism & $-.26^{*}$ & .07 \\
Challenge & .13 & .12 \\
Co-workers & .17 & $-.22^{*}$ \\
Lifestyle & $.20^{*}$ & $.35^{* * *}$ \\
Supervisory relations & .14 & $.62^{* * *}$ \\
Workplace & $.43^{* *}$ & 5.65 \\
$R^{2}$ & 2.62 & \\
$F$ & & \\
\hline
\end{tabular}

$* p<.10 ; * * p<.01 ; * * * p<.001$

In contrast, participants who enjoyed their work greatly appreciated values related to interpersonal relations and, particularly, being respectful, fair, and kind in relationships with others. Moreover, participants with a high level of work enjoyment placed less importance on fun and pleasure. This sheds some light on possible reasons why those who enjoyed their work neglect leisure time and pleasure in their life (Machlowitz 1980), and this might explain why they have difficulties with recovery (Binnewies and Sonnentag 2008; Taris et al. 2005).

It should be noted that correlations between drive to work and work enjoyment as well as other values, representing low-order (vital values) and higher order (truth and aesthetic values, secular and religious holy values), in the ideal value hierarchy were insignificant. Thus, our results confirm not fully, but partially hypotheses 1 and 2 . However, this study provides a valuable contribution to the existing literature. It showed that drive to work and work enjoyment represent different levels of psychological and social adjustment based on their diverse relationships to moral values which have a high position in the ideal value hierarchy.

It was predicted, on the basis of previous research, that the drive to work would be related to extrinsic work values (income, management, prestige, promotion, and security) and work enjoyment would be related to intrinsic work values (creativity, independence, and intellectual stimulation). Our results, however, did not support hypotheses 3 and 4 completely. The study found that the drive to work was positively related to extrinsic work values, such as income, as well as the intrinsic work value of intellectual stimulation. This workaholism component also was positively related to supervisory relations. Moreover, participants who had an inner compulsion to work hard did not appreciate security, which is an extrinsic work value, or other values, such as challenge and achievement. Accordingly, those who enjoyed their work appreciated independence, which is an intrinsic work value, the most, along with work 
conditions, which does not fall under this intrinsic category. The results supporting hypothesis 4 are that work enjoyment was negatively related to extrinsic work values, such as management, security, and prestige. In addition, work enjoyment was negatively related to some other values (aesthetics and supervisory relations).

Although the results of study 2 did not confirm the assumptions about the distinctive relationship between the components of workaholism and extrinsic and intrinsic work values, it provided additional evidence about the sources of motivation of workaholics. It is possible that individuals who feel internal pressure to work hard are motivated both by the financial revenue they get from their work and by independent thinking; they are keen on learning how and why things work. Furthermore, a collegial relationship with an individual's supervisor is important to them. Importantly, these findings confirm previous results that workaholics can be motivated by external and internal motivation (Van den Broeck et al. 2011).

Regarding individuals who enjoy their work, the present study found that they are motivated mostly by opportunities to control the manner in which they perform their work and by pleasant working conditions. They do not seek security or prestige in their work and they are not motivated to manage others or have a relationship with supervisors. This may signify that they are mainly motivated by autonomy in their work and want to have good workplace conditions to perform their work.

It should be noted that work values, in comparison to life values, were more significant predictors of both workaholism components. This result can be explained, in part, by research demonstrating that internal general causes are less predictive than situational variables in determining behaviour (e.g. Darley and Latané 1968; Mischel 1973). Work values explained over $40 \%$ of the variance in the drive to work and over $60 \%$ of the variance in work enjoyment.

\section{Practical Implications}

Our findings have practical implications. Work values, in particular, can be used by organisations and Human Resources practitioners in the analysis of workaholics' motivation to work. Moreover, organisations should diagnose work values and take into account the distinction between intrinsic versus extrinsic values while selecting employees. The outcome of this could be lesser drive to work and greater work enjoyment among their employees. Finally, the organisational culture should be focused on the intrinsic value of independence and the creation of a friendly (tiny and quiet) workplace in order to stimulate work enjoyment.

\section{Limitations and Future Research Directions}

Some limitations of the present studies should be noted. First, all the data were collected using self-reports, raising the possibility of common method variance and response set tendencies. Although, there is no other option than measuring individual life and work values by selfreports, it is crucial for future research to employ multiple methods and use, for instance, peers' or supervisor' observations about workaholic behaviours. Second, the data were collected at only one point in time, making an examination of causality impossible. Future research which uses a longitudinal approach is needed. It is beneficial not only for examining causality, but also for analysing the changes in workaholism components with regard to organisational 
support and the reward of values which may guide the behaviours associated with workaholism. Third, we examined only two workaholism components in relation to life and work values in our study. A study employing different measures of workaholism and using more workaholism components (e.g. working excessively, tolerance, withdrawal) seems to be a useful next step. Fourth, we analysed data from a small sample of participants employed in one production company in study 2 , which makes it impossible to generalise those findings. It is important that future research include larger samples and more heterogeneous populations. A final limitation is that three scales (co-workers, achievement, lifestyle) used to measure work values in study 2 have alfa levels below .60, which do not warrant stability of responses.

\section{Compliance with Ethical Standards}

All procedures followed were in accordance with the ethical standards of the responsible committee on human experimentation (institutional and national) and with the Helsinki Declaration of 1975, as revised in 2000 (5).

Informed Consent Informed consent was obtained from all individual participants included in the study.

Conflict of Interest Diana Malinowska \& Aleksandra Tokarz declare that they have no conflict of interest.

Open Access This article is distributed under the terms of the Creative Commons Attribution 4.0 International License (http://creativecommons.org/licenses/by/4.0/), which permits unrestricted use, distribution, and reproduction in any medium, provided you give appropriate credit to the original author(s) and the source, provide a link to the Creative Commons license, and indicate if changes were made.

\section{References}

Allport, G. W. (1961). Pattern and growth in personality. New York: Holt, Rinehart, and Winston.

Andreassen, C. S. (2014). Workaholism: an overview and current status of the research. Journal of Behavioral Addictions, 3(1), 1-11.

Andreassen, C. S., Ursin, H., \& Eriksen, H. R. (2007). The relationship between strong motivation to work, "workaholism", and health. Psychology and Health, 22, 615-629.

Andreassen, C. S., Hetland, J., \& Pallesen, S. (2014). Psychometric assessment of workaholism measures. Journal of Managerial Psychology, 24(1), 7-24.

Aziz, S., \& Zickar, N. J. (2006). A cluster analysis investigation of workaholism as a syndrome. Journal of Occupational Health Psychology, 11(1), 52-62.

Bargh, J. A., Gollwitzer, P. M., \& Oettingen, G. (2010). Motivation. In S. Fiske, D. Gilbert, \& G. Lindzey (Eds.), Handbook of social psychology (5th ed., pp. 268-316). New York: Wiley.

Binnewies, C., \& Sonnentag, S. (2008). Recovery after work: unwinding from daily job stress. In R. J. Burke \& C. L. Cooper (Eds.), The long work hour culture: causes consequences and choices (pp. 275-293). Lancaster: Emerald Group Publishing Limited.

Brown, D. (1996). Brown's values-based, holistic model of career and life-role choices and satisfaction. In D. Brown, L. Brooks, \& Associates (Eds.), Career choice and development (3rd ed., pp. 337-372). San Francisco: Jossey-Bass.

Brzozowski, P. (1992). Hierarachia wartości Maxa Schelera. Teoria a fakty empiryczne [Max Scheler's hierarchy of values. Theory and empirical facts]. Przeglad Psychologiczny, 35(3), 329-338.

Brzozowski, P. (1995). Skala wartości Schelerowski - SWS. Podręcznik [Scheler's value scale. A handbook]. Warszawa: Pracownia Testów Psychologicznych PTP.

Brzozowski, P. (2005). Uniwersalna hierarchia wartości. Fakt czy fikcja? [The universal hierarchy of values. Fact or fiction?]. Przeglad Psychologiczny, 48(3), 261-276. 
Brzozowski, P. (2007). Wzorcowa hierarchia wartości. Polska, europejska czy uniwersalna? Psychologiczne badania empiryczne [An ideal value hierarchy. Polish, European or universal? Empirical psychological research]. Lublin: Wydawnictwo UMCS.

Burke, R. J. (2000a). Workaholism in organizations: concepts, results and future research directions. International Journal of Management Reviews, 84, 167-172.

Burke, R. J. (2000b). Workaholism and extra-work satisfactions. International Journal of Organizational Analysis, 7, 352-364.

Burke, R. J. (2000c). Workaholism in organizations: psychological and physical well-being consequences. Stress Medicine, 16(1), 11-16.

Burke, R. J. (2008). Working to live or living to work: should individuals and organizations care? Journal of Business Ethics, 2(1), 1-16.

Burke, R. J., \& Fiksenbaum, L. (2008). Work hours, work intensity, and work addictions. In R. Burke (Ed.), Workaholism and long hours working (pp. 3-37). Cheltenham: Edward Elgar.

Burke, R. J., Richardsen, A. M., \& Mortinussen, M. (2004). Workaholism among Norwegian managers: work and well-being outcomes. Journal of Organizational Change Management, 17(5), 459-470.

Burke, R. J., Matthiesen, S. B., \& Pallesen, S. (2006). Personality correlates of workaholism. Personality and Individual Differences, 40, 1223-1233.

CBOS. (2012). Mobliność na codzień. Komunikat z badań nr BS/104/2012 [mobility in every day life. Research report]. Warszawa.

Clark, M. A., Michel, J. S., Zhdanova, L., Pui, S. Y., \& Baltes, B. B. (2014). All work and no play? A meta-analytic examination of the correlates and outcomes of workaholism. Journal of Management, 42(7), 786-791.

Darley, J. M., \& Latané, B. (1968). Bystander intervention in emergencies: diffusion of responsibility. Journal of Personality and Social Psychology, 8, 377-383.

Dawis, R. V., \& Lofquist, L. H. (1984). A psychological theory of work adjustment. Minneapolis, MN: University of Minnesota Press.

Deci, E. L., \& Ryan, R. M. (1985). Intrinsic motivation and self-determination in human behavior. New York: Plenum Press.

Deci, E. L., \& Ryan, R. M. (2000). Self-determination theory and the facilitation of intrinsic motivation, social development and well-being. American Psychologist, 55(1), 68-78.

George, J. M., \& Jones, G. R. (1997). Experiencing work: values, attitudes and moods. Human Relations, 50(4), 393-416.

Graves, L. M., Ruderman, M. N., Ohlott, P. J., \& Weber, T. J. (2012). Driven to work and enjoyment of work: effects on managers' outcomes. Journal of Management, 38, 1655-1680.

Griffiths, M. D., Demetrovics, Z., \& Atroszko, P. A. (2018). Ten myths about work addiction. Journal of Behavioral Addictions, 7, 1-13.

Guttman, L. (1982). What is not what in theory construction. In R. M. Hauser, D. Mechanic, \& A. Haller (Eds.), Social structure and behavior (pp. 331-348). New York: Academic Press.

Hyde, R. E., \& Weathington, B. L. (2006). The congruence of personal life values and work attitudes. Genetic, Social, and General Psychology Monographs, 132(2), 151-190.

Jellinek, E. M. (1960). The disease concept of alcoholism. New Haven: Hillhouse.

Johnstone, A., \& Johnston, L. (2005). The relationship between organizational climate, occupational type and workaholism. New Zealand Journal of Psychology, 34, 181-188.

Kanai, A., \& Wakabayashi, M. (2001). Workaholism among Japanese blue-collar employees. International Journal of Stress Management, 8(2), 129-145.

Kasser, T. (2002). Sketches for a self-determination theory of values. In E. L. Deci \& R. M. Ryan (Eds.), Handbook of self-determination research (pp. 123-140). Rochester, NY: University of Rochester Press.

Killinger, B. (1991). Workaholics: the respectable addicts. New York: Simon \& Schuster.

Knoop, R. (1994). Work values and job-satisfaction. Journal of Psychology, 128, 683-690.

Latham, G. P. (2007). Work motivation. Thousand Oaks, CA: Sage.

Liang, Y.-W., \& Chu, C.-M. (2009). Personality traits and personal and organizational inducements: antecedents of workaholism. Social, Behavior and Personality, 37, 645-660.

Locke, E. A., \& Henne, D. (1986). Work motivation theories. In C. Cooper \& I. Robertson (Eds.), International review of industrial and organizational psychology (pp. 1-35). Chichester, England: Wiley Ltd.

Machlowitz, M. (1980). Workaholics. Reading: Addison Wesley.

Malinowska, D. (2018). How to counter the ten myths about work addiction. Three postulates for future research. Journal of Behavioral Addictions, 7(4), 871-874.

Malinowska, D., Tokarz, A., \& Gad, N. (2010). Wstępne badania nad adaptacją skali Workaholism Battery (Work-BAT) Spence i Robbins [preliminary study on Spence and Robbins's Workaholism Battery (WorkBAT)]. Studia Psychologiczne, 48(3), 35-42. 
Malinowska, D., Tokarz, A., \& Wardzichowska, A. (2018). Job autonomy in relation to work engagement and workaholism: mediation of autonomous and controlled work motivation. International Journal of Occupational Medicine and Environmental Health, 31(4), 445-458.

McClelland, D. C. (1986). Human motivation. Glenview: Scott, Foresman and Co.

McMillan, L. H. W., O’Discroll, M. P., Brady, E. C., \& March, N. V. (2002). A multifaceted validation study of Spence and Robbins' (1992) workaholism battery. Journal of Occupational and Organizational Psychology, $75,357-368$.

Mischel, W. (1973). Toward a cognitive social learning reconceptualization of personality. Psychological Review, $80,252-283$.

Naughton, T. J. (1987). A conceptual view of of workaholism and implications for career counseling and research. The Career Development Quarterly, 35, 180-187.

Ng, W. H., Sorensen, K. L., \& Feldman, D. C. (2007). Dimensions, antecedents, and consequences of workaholism: a conceptual integration and extension. Journal of Organizational Behavior, 28(1), 111-136.

Nord, W., Brief, A., Atieh, J., \& Dohorty, E. (1990). Studying meanings of work: the case of work values. In A. Brief \& W. Nord (Eds.), Meanings of occupational work (pp. 255-296). Lexington, MA: Lexington Books.

Oates, W. (1971). Confessions of a workaholic: the facts about work addiction. New York: World Publishing.

Paluchowski, W. J., \& Hornowska, E. (2003). Pracoholizm a system wartości i uwarunkowania temperamentalne. In S. A. Witkowski (Ed.), Psychologiczne wyznaczniki sukcesu w zarzadzaniu. Tom IV [Psychological determinans of success in managament.] (pp. 295-319). Wrocław: Wydawnictwo Uniwersytetu Wrocławskiego.

Robinson, B. E. (1996). The psychosocial and familial dimension of work addiction: preliminary perspective hypotheses. Journal of Counseling and Development, 74, 447-452.

Rokeach, M. (1973). The nature of human values. New York: The Free Press.

Rokeach, M. (1979). Understanding human values. New York: The Free Press.

Sagie, A. (1993). Measurement of religiosity and work obligations among Israeli youth. Journal of Social Psvchology, 133, 529-537.

Schaufeli, W. B., Taris, T. W., \& van Rhenen, W. (2008). Workaholism, burnout, and work engagement: three of a kind or three different kinds of employee well-being? Applied Psychology: An International Review, 57(2), 173-203.

Taris, T. W., Schaufeli, W. B., \& Verhoeven, L. C. (2005). Workaholism in the Netherlands: measurement and implications for job strain and work-nonwork conflict. Applied Psychology: An International Review, 54, 37-60.

Schaufeli, W. B., Salanova, M., Gonzalez-Romá, V., \& Bakker, A. B. (2002). The measurement of engagement and burnout: a confirmative analytic approach. Journal of Happiness Studies, 3, 71-92.

Scheler, M. (1975). Aprioryczne powiazania o charakterze starszeństwa między modalnościami wartości. [A priori seniority associations between modalities of values]. Warszawa: Wiedza Powszechna.

Schwartz, S. H. (1992). Universals in the content and structure of values: theoretical advances and empirical tests in 20 countries. Advances in Experimental Social Psychology, 25, 1-65.

Schwartz, S. H. (2005). Basic human values: their content and structure across countries. In A. Tamayo \& J. B. Porto (Eds.), Valores e comportamento nas organizações [Values and behavior in organizations] (pp. 21-55). Petrópolis: Vozes.

Scott, K. S., Moore, K. S., \& Miceli, M. P. (1997). An exploration of the meaning and consequences of workaholism. Human Relations, 50, 287-314.

Seifert, K. H., \& Bergmann, C. (1983). Deutschsprachige Adaptation des Work Values Inventory von Super [German adaptation of Super's Work Values Inventory]. Psychologie und Praxis. Zeitschrift fur Arbeits- und Organisationspsychologie, I, 160-172.

Sheldon, K. M., \& Elliot, A. J. (1998). Not all personal goals are "personal": comparing autonomous and controlling goals on effort and attainment. Personality and Social Psychology Bulletin, 24, 546-557.

Sheldon, K. M., \& Elliot, A. J. (1999). Goal striving, need satisfaction, and longitudinal well-being: the selfconcordance model. Journal of Personality and Social Psychology, 76, 482-497.

Snir, R., \& Harpaz, I. (2012). Beyond workaholism: towards a general model of heavy work investment. Human Resource Management Review, 22(3), 232-243.

Spence, J. T., \& Robbins, A. S. (1992). Workaholism: definition, measurement, and preliminary results. Journal of Personality Assessment, 58(1), 160-178.

Super, D. E. (1953). A theory of vocational development. American Psychologist, 8, 185-190.

Super, D. E. (1970). Manual: work values inventory. Boston: Houghton Mifflin.

Super, D. E. (1985). Coming of age in Middletown. The American Psychologist, 40, 405-414.

Thoresen, C. J., Kaplan, S. A., Barsky, A. P., Warren, C. R., \& de Chermont, K. (2003). The affective underpinnings of job perceptions and attitudes: a meta-analytic review and integration. Psychological Bulletin, 129, 914-945. 
Tischner, J. (1984). Etyka wartości i nadziei [Value and hope ethics]. In J. Tischner, J. Paściak, J. A. Kłoczowski, \& D. von Hildenbrandt (Eds.), Wobec wartości [Towards values] (pp. 88-92). Poznań: Wydawnictwo w drodze.

Van Beek, I., Taris, T., \& Schaufeli, W. B. (2011). Workaholic and work engaged employees: dead ringers or worlds apart? Journal of Occupational Health Psychology, 16, 468-482.

Van den Broeck, A., Schreurs, B., De Witte, H., Vansteenkiste, M., Germeys, F., \& Schaufeli, W. B. (2011). Understanding workaholics' motivations: a self-determination perspective. Applied Psychology: An International Review, 60(4), 600-621.

Wojdylo, K., Baumann, N., Buczny, J., Owens, G., \& Kuhl, J. (2013). Work craving: a conceptualization and measurement. Basic and Applied Social Psychology, 35(6), 547-568.

Zalewska, A. (2000). Adaptacja kwestionariusza "Orientacja na Wartości Zawodowe" Seiferta i Bergmanna do warunków polskich [The adaptation of Seifert's and Bergman's questionnaire "Work value orientations" into Polish conditions]. Studia Psychologiczne, 38(1), 57-77.

Publisher's Note Springer Nature remains neutral with regard to jurisdictional claims in published maps and institutional affiliations. 